\title{
Sex-based spatial segregation of adult bull sharks, Carcharhinus leucas, in the New Caledonian great lagoon
}

\author{
Jonathan Mark WERRY ${ }^{1,2, a}$ and Eric CLUA ${ }^{3}$ \\ 1 Australian Rivers Institute and School of Environment, Griffith University, Gold Coast, 4222 Queensland, Australia \\ 2 Ocean and Coast Research, PO Box 299, Main Beach, 4217 Gold Coast, Australia \\ ${ }^{3}$ French ministry of Agriculture and Fisheries, 51 rue de Vaugirard, 75015 Paris Cedex, France
}

Received 7 January 2013; Accepted 3 September 2013

\begin{abstract}
Conservation of threatened large sharks and management of shark-human interactions requires an understanding of shark occurrence and movement patterns. Here, we present the first catch, movement and behaviour data of adult bull sharks, Carcharhinus leucas, in New Caledonia. Amongst six adult C. leucas tagged with passive acoustic tags, four females were caught in coastal waters while males were only found at an isolated oceanic barrier coral reef over $100 \mathrm{~km}$ from the nearest river mouth. Two females were monitored in the southern New Caledonia lagoon for 707 and 208 days respectively and displayed classical transient behaviour and sporadic short-term residency around a coastal reef bay, with movements in and out a river detected prior to spring. Adult $C$. leucas in New Caledonia may develop a sex-based spatial segregation with an atypical presence of adult males in oceanic environments, probably influenced by the unique estuarine-marine continuum of the New Caledonian great lagoon.
\end{abstract}

Keywords: Habitat use / Acoustic telemetry / Fish movement / Conservation / Bull shark / Pacific Ocean

\section{Introduction}

Global declines in large shark populations have been documented with concerns for top-down effects on associated ecosystems (Baum et al. 2003; Myers and Worm 2003; Baum and Myers 2004). For many sharks, these pressures are exacerbated by slow growth, late onset of sexual maturity and low fecundity (Hoenig and Gruber 1990; Cortes 2000; Mollet and Cailliet 2002), making it increasingly important to identify the movements, habitat and behaviour of adult sharks for conservation and management of shark to human interactions. The bull shark, Carcharhinus leucas, is a large shark species with a cosmopolitan distribution, growing to $4 \mathrm{~m}$ (Compagno 2002; McCord and Lamberth 2009). It is also one of a few, euryhaline elasmobranchs that utilises a range of salinities throughout its life-cycle (Thorson 1971). Neonates occupy 6-12 ppt low saline nursery habitats (Thorson et al. 1973; Pillans et al. 2006; Heupel and Simpfendorfer 2008), juveniles occur in rivers and estuarine habitats (Simpfendorfer et al. 2005; Werry et al. 2011, 2012) and adults in nearshore marine habitats (Curtis et al. 2011). Adult males may remain offshore, while pregnant females may return to rivers to pup (Werry et al. 2011, 2012; Tillett et al. 2012). Recent studies have also shown

\footnotetext{
a Corresponding author: jwerry@oc-research.com
}

the use of coastal habitats for older and larger bull sharks (Brunnschweiler and Baensch 2011; Tillet et al. 2011; Werry et al. 2011; Hammerschlag et al. 2012), but the literature examining the movement patterns of adult bull sharks is rare, especially regarding their behaviours away from shallow coastal areas. Whether more oceanic habitats should be considered as essential for this species is uncertain due to the paucity of data. Furthermore, as females rather than males return to rivers to pup, sex-based segregation may occur among adults of this species, however these patterns have not been investigated in many areas of the southwest Pacific, including New Caledonia. Despite its wide distribution, regulated and illegal fishing and habitat modification have directly resulted in a "Near-Threatened" global status for bull sharks on the IUCN Red List (Cavanagh et al. 2003; IUCN 2008).

Obtaining data on large adult sharks is limited by their natural low abundances, wide distribution, elusive behaviour and challenge associated with capture. The recent availability of passive acoustic telemetry however, has greatly advanced the ability to monitor shark behaviour in shallow reef and coastal environments (Lacroix and McCurdy 1996; Voegeli et al. 1998; Lacorix and Voegeli 2000; Heupel et al. 2006). This technology has been successfully used to determine the patterns of occupancy and movement of sharks in estuaries, 


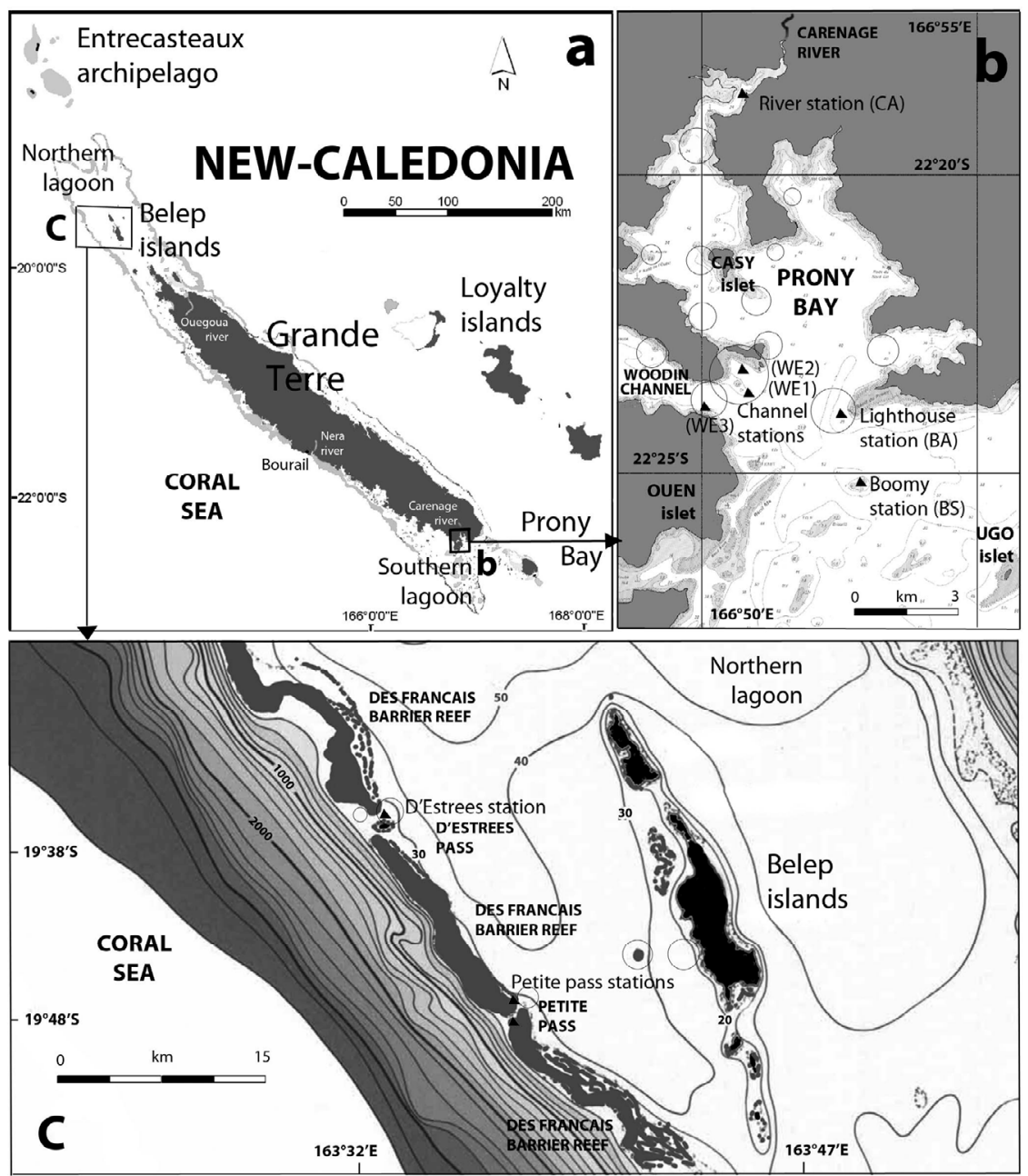

Fig. 1. Map of New Caledonia (a), with close up of the southern (b), and northern lagoon (c), with fishing and tagging locations in Prony Bay (b), including six VR2W station locations, and in Belep islands (c), including three VR2W station locations (D'Estrees and Petite pass reef passages). VR2W receivers are shown by $\boldsymbol{\Delta}$ and fishing areas are shown by circles.

bays, nearshore and reef areas (Heupel and Hueter 2002; Heupel et al. 2004; Simpfendorfer et al. 2008; Yeiser et al. 2008; Werry et al. 2011). In conjunction with complementary techniques such as micro-chemistry, acoustic telemetry has also enabled quantification of ontogenetic transitions in habitat use by bull sharks (Werry et al. 2011). However, for adult bull sharks in New Caledonia, movement, occurrence patterns and behaviour remain largely unknown. The New Caledonian lagoon was included in 2008 within the UNESCO world heritage as a unique place, based on its comparatively immense surface area $\left(22175 \mathrm{~km}^{2}\right)$ on a global scale and the diversity of reef ecosystems. This diversity offers a unique complex for the detection of habitat specificity and movement patterns of sharks.

Investigating the movement, ecology and behaviour of bull sharks in different parts of the world is important for international, national and localised conservation strategies. For example, acoustic telemetry has demonstrated consistent patterns in strong site fidelity in different oceans of the world for the grey reef shark, Carcharhinus amblyrhynchos, including Ningaloo fringing reef (Speed et al. 2011), the Rowley Shoals coral atoll (Field et al. 2011), and Osprey Reef in the
Coral Sea (Barnett et al. 2012), however this pattern does not hold true for grey reef sharks in the northern Great Barrier Reef, Australia (Heupel et al. 2010). This example illustrates the need to determine movement and occurrence patterns of sharks in different areas of the globe for the effective localised management and conservation of the species. In this study the occurrence and movements of bull sharks in different habitats were examined and in so doing we investigated whether sex-based segregation occurs among adult bull sharks in New Caledonia.

\section{Methods}

New Caledonia consists of several large islands of which the largest "Grande Terre" is approximately $400 \mathrm{~km}$ by $50 \mathrm{~km}$ and is characterised by a barrier reef with interspersed channels between lagoon habitats and deep drop-offs ( $>1000 \mathrm{~m})$ to open ocean environments (Fig. 1a). Channels and lagoons are typically 20 to $40 \mathrm{~m}$ in depth. The southern area of Grande Terre has a vast lagoon area typified by coral reefs, bommies and open sand and rubble sea floor and sparse deep water 
seagrass meadows with several creeks and rivers that discharge large amounts of freshwater. Prony Bay is the largest bay in this southern area, with a very high terrigeneous influence based on several rivers and creeks (Fig. 1b). The north of Grande Terre comprises an extended lagoon enclosed by two large barrier reefs each of about $150 \mathrm{~km}$ in length and a small archipelago lies in the central area approximately 10 to $50 \mathrm{~km}$ from the barrier reefs on either side. The barrier encompasses several reef passages and a fragmented area at the very end of the lagoon (Fig. 1c). Mangrove lined river systems represent a surface of 25900 ha and occur along both the east (12\%) and mainly west $(88 \%)$ coasts of Grande Terre in strong connection with river mouths (Virly 2008).

Twenty large shark surveys were undertaken in bay, lagoon, channel and reef edge habitats in New Caledonia from late 2008 to 2011 around Prony Bay and Belep archipelago (Fig. 1a,b,c). We used setlines baited with tuna heads that were checked at least every two hours. Captured sharks were maintained in a specially designed harness next to an anchored research vessel with the sharks head placed into the current (see Werry et al. 2012). Total length, sex and condition were recorded for each shark captured and adult bull sharks were surgically implanted in the perineal cavity with a VEMCO Rcode V16 transmitter. Transmitters had a unique pulse series for each shark with randomly spaced transmission intervals from $40-80 \mathrm{~s}$ or $50-130 \mathrm{~s}$, and a battery life of at least 24 or 28 months, respectively. The passive movements of the acoustically-tagged sharks and their duration of occupation of habitats were quantified over 30 months from July 2009 to November 2011 using an array of 9 VEMCO VR2/VR2W omni-directional acoustic receivers (Amirix Systems Inc., Nova Scotia, Canada) strategically deployed at various sites in Prony Bay and at passes in Belep (Fig. 1b,c). Six receivers were deployed in the southern lagoon of Grande Terre, one in upper reaches of Prony Bay at the entrance to the Carenage River, four at the reef edge in Woodin Channel and at the entrance to Prony Bay and a single receiver on a large bommie within the mid-southern lagoon (Fig. 1b). In addition, our study could benefit from the setting of several VR2W acoustic receivers deployed in the framework of a study on reef bony fishes on the western coast of Grande Terre (close to Bourail) (Fig. 1a). The three receivers in the northern lagoon were all deployed at passes in the barrier reef (Fig. 1c). Several rivers were also sporadically line fished (total fishing effort of 5 full days with small drum lines), in particular the Nera River and the Ouegoua River (North of Grande Terre) (Fig. 1a).

The maximum tag ranges, habitat complexity, and acoustic receiver sites meant that the presence of each tagged bull shark was documented within $600 \mathrm{~m}$ of the receiver. Tag range testing was done by towing a test tag away from the acoustic receiver until the rate of detections was less than $50 \%$. Prior to deployment of acoustic receivers, each acoustic receiver was wrapped with duct tape and was attached to a navigation marker $5 \mathrm{~m}$ below mean low water mark or moored on concrete filled tyres on reef edges at 16 to $20 \mathrm{~m}$ (as per Otway and Ellis 2011). Retrieval, data download, replacement of batteries and redeployment of the acoustic receivers was done at 6 to 12 monthly intervals. Following data download, the detections were sorted by shark ID, site, date and time. This permitted the documentation of the length of time an individual was monitored based on release date until date of last detection, the number of days an individual was present during the monitoring period, timing and duration of occupation of particular sites, the movements of individuals among sites and the presence of diurnal patterns. The "proportion of days monitored/days" was calculated as the percentage of days with a minimum of one detection over the total monitoring period. Significant differences in proportion of detections between night and day were determined using Chi-square tests in order to determine a potential pattern of movements based on nycthemeral rhythms.

\section{Results}

A total fishing effort of 24 days (with an average of 4 drumlines per day) was deployed between October 2008 and November 2011. It allowed the capture of eight adult bull sharks, and the tagging of six animals, four females and two males respectively (Table 1$)$. One female ( $2.6 \mathrm{~m} \mathrm{TL})$ and one male (approx. $2.6 \mathrm{~m} \mathrm{TL}$ ) were found dead on the hook, in spite of the careful monitoring of the lines.

Interestingly, no adult male bull sharks were captured within bay or lagoon habitats. All adult males were captured in the Northern Province in March 2010 within minutes of each other on the same day and sampling site at the interface with the open ocean $(<1500 \mathrm{~m}$ deep) and barrier reef (Table 1). This one-time observation of adult male bull sharks occurred at a site over $100 \mathrm{~km}$ from the first large river mouth of "Grande Terre" (Fig. 1a,c). During this capture and tagging effort, one large bull shark (\#2.6 m TL based on head width) was also consumed by other large sharks at this aggregation site (Clua and Werry unpublished data). Further fishing efforts in 2011 at the same location, but during a different period of the year (i.e., November), resulted in no further capture of bull sharks. VR2W acoustic receivers deployed on the ocean side of this site directly after the male bull sharks were tagged and released in 2010 had no detections from 2010 to 2011, indicating all the tagged sharks probably left the area directly after tagging and did not return. The two male bull sharks tagged in the north were also not detected on other arrays in the southern lagoon or along the west coast of New Caledonia (Bourail area).

In contrast, four adult female bull sharks were only caught in Prony bay and close to Belep Island well within the "Grande Terre" lagoon and close (within several km's) to land (Table 1). Females tagged with acoustic tags at Prony bay showed variable movement patterns, with a total of 100766 detections between July 2009 and November 2011 (Fig. 2, Table 1). One $3 \mathrm{~m}$ female was also detected moving into the Carenage River flowing into Prony Bay in spring prior to the pupping period suggested by Werry et al. (2012), although occurrence was predominantely in the Woodin channel (Fig. 3). Subsequent fishing efforts in the numerous rivers along the west coast of New Caledonia revealed the presence of several small juvenile bull sharks, both male and female, in the Ouegoua and Nera rivers (Fig. 1, Table 1). In 2011, this adult 


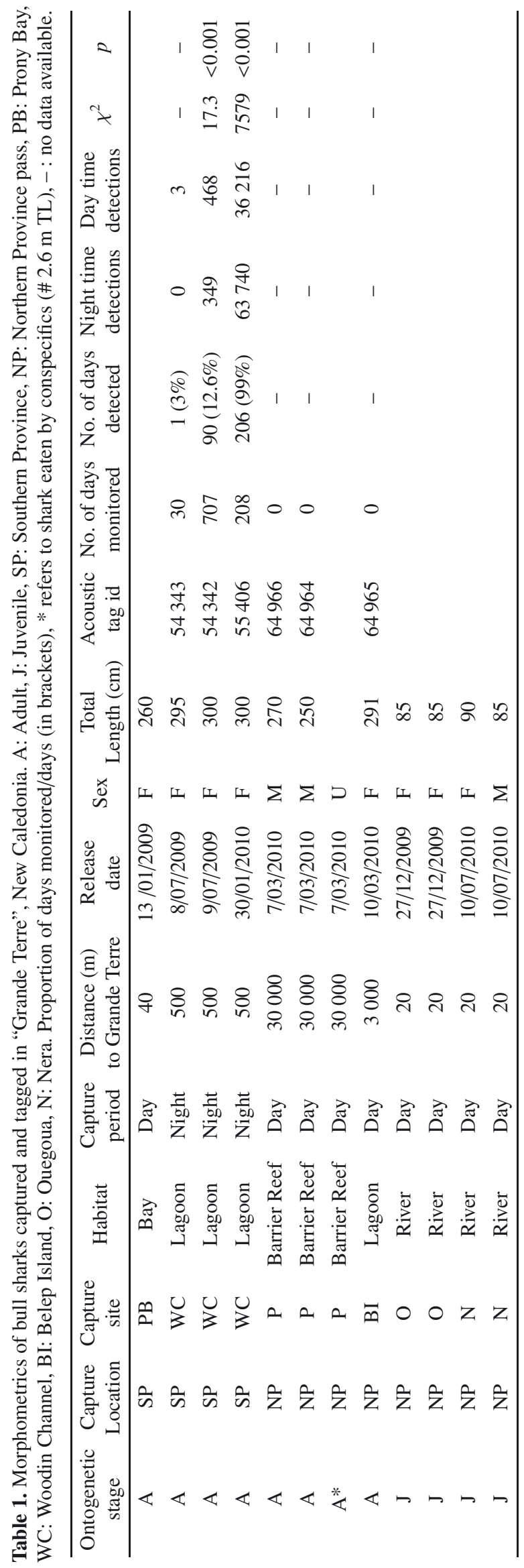

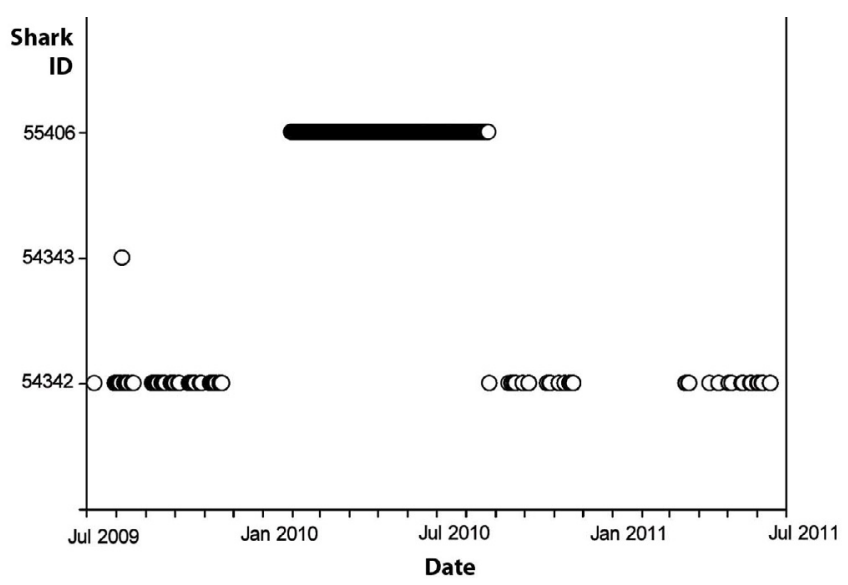

Fig. 2. Temporal occurrence of three adult female bull sharks with acoustic tags in Prony bay, southern New Caledonia.

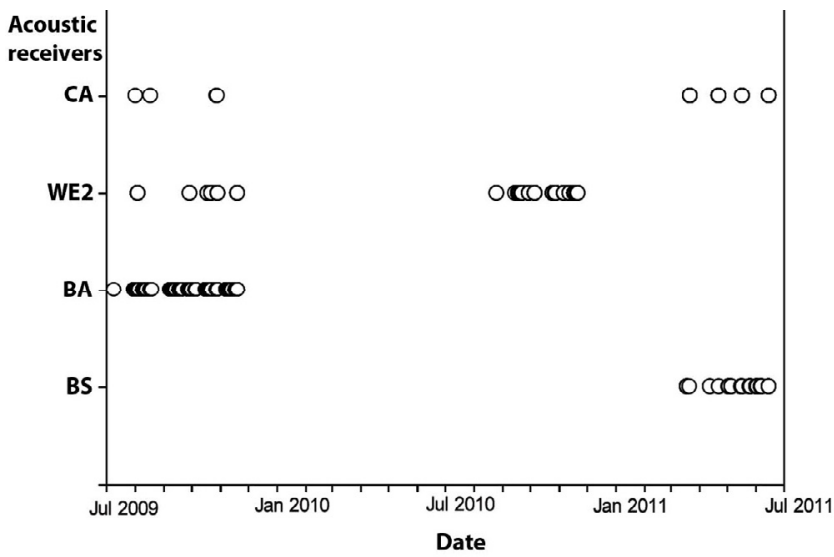

Fig. 3. Individual patterns of movement for adult female bull shark ID 54342 tagged with an acoustic tag in Prony bay, southern New Caledonia (see Fig. 1a for location of the acoustic receivers).

shark was also detected moving towards the river in other periods of the year. This individual was detected periodically throughout the study with absences of several months before reoccurrence on the Prony Bay array providing 817 detections over a 707 day monitoring period (Table 1, Fig. 3). This shark had significantly more detections during the day. One other adult female bull shark was detected briefly after tag and release and accounted for only 3 detections (Fig. 2). This shark was subsequently not detected again throughout the study period. In addition, one female bull shark was captured in the Prony Bay area in an emancipated and extremely poor condition. This bull shark had numerous fishing lures and hooks embedded in the caudal fin along with fishing line embedded in inflamed tissue and cutting through the posterior and dorsal flesh between the second dorsal fin and the caudal peduncle. This shark was captured on a drumline set in the same area, but rigged with rotten bait in order to capture tiger shark rather than bull sharks. The fishing lines were removed from the flesh and hooks removed from the caudal fin. This shark was also revitalised and closely monitored while in a specially designed shark harness (Werry et al. 2012) prior to release. This shark revealed continuous detections from January to August 2010 
and accounted for 99956 of the detections with significantly more detections during the night.

\section{Discussion}

Bull sharks are generally considered shallow water coastal species. The unusual occurrence of large adult male bull sharks at a remote coral reef and adjacent to deep oceanic waters highlights the variability in habitat use of this species as adults. Data on adult bull sharks is scant and the importance of oceanic habitats for the species is poorly understood. While our data set is small it does reveal very interesting and possibly new insights in adult bull shark occurrence patterns. Many of the passes in the northern lagoon barrier reef are important areas for large Malabar grouper, Epinephelus malabaricus, spawning aggregations, providing potential seasonally abundant food sources for adult bull sharks (Chauvet unpublished data). However, our underwater observations, after tag and release of the adult male bull sharks, did not reveal the presence of grouper aggregations suggesting other drivers for bull shark occurrence at this location. Besides the hypothesis linked to spawning aggregations as site specific feeding opportunities for the adult bull sharks, the overall species diversity and very high biomass $\left(>250 \mathrm{~g} \mathrm{~m}^{-2}\right)$ of teleost fishes encountered in the northern lagoon and particularly in the barrier reef passages (Letourneur et al. 2000), could be attractive enough as a motivating food source for male bull sharks to use the outer barrier reef. Overlap with bull shark movement and their prey has been observed in recent satellite telemetry studies. For example, the core area of bull shark activity found within the northwestern area of Florida Bay, USA, was likely driven by the high abundance of teleost prey concentrated there (Hammerschlag et al. 2012). In addition, by conducting shark and fish surveys throughout Florida Bay, Torres et al. (2006) found that the abundance of seven species of sharks (including bulls) in the northwestern area of Florida Bay was highly correlated with the abundance of 45 teleost species. This hypothesis is however mitigated by Speed et al. (2010) who suggest that habitat specificity for sharks is more often correlated with environmental conditions such as depth, salinity, and substratum rather than prey availability, although recognizing migration patterns are often driven by prey and mating requirements.

The subsequent absence of male bull shark detections at this remote location also suggests the tagged sharks moved away from the area and did not return in the following year. Hence the initial presence of adult male bull sharks at this location may have also been due to an unusual anomaly driven by a shift in normal environmental conditions such as water currents and temperature rather than aggregations of prey such as groupers. Alternatively, male bull sharks may migrate to feeding hotspots using random prey search patterns similar to that of adult tiger sharks (Meyer et al. 2009), switching their movement patterns and foraging strategies to take advantage of different prey before returning to shallower coastal areas frequented by females in search of mates. For the period of our study, our data indicated no capture of adult male bull sharks in shallow coastal areas in New Caledonia, although evidence strongly shows that they occur in shallow coastal areas in other regions of the world (Brunnshweiler et al. 2010;
Brunnschweiler and Barnett 2013). The inclusion of more oceanic habitat by adult bull sharks may also be a strategic response to reduce exposure to anthropogenic impacts including reduced water quality, pollution from mining and urban runoff, reductions in their prey and habitat modifications tied to freshwater environments and shallow nearshore areas (Werry et al. 2011, 2012; Curtis et al. 2013). In addition, this atypical location of adult male animals of a species usually attached to coastal ecosystems, might be facilitated by the specificities of the New Caledonian great lagoon. The high variety of adjacent reef ecosystems and the size of the greatest closed lagoon of the world, constitutes a vast estuarine-marine continuum which may lead this species to use a wider range of habitats without having to cruise in the open ocean.

The capture of large adult female bull sharks in shallow coastal areas is consistent with other studies (e.g., Curtis et al. 2011; Werry et al. 2011). Moreover, while our sample sizes are small, our data suggests a possible trend towards sex-based segregation among adult bull sharks in New Caledonia. Sexbased aggregations and spatial segregation of sharks has been observed in numerous pelagic shark species, including Scallop hammerhead, Sphyrna lewini (Klimley 1987; Noriega et al. 2011), short-fin mako, Isurus oxyrinchus, blue shark, Prionace glauca (Mucientes et al. 2009) and coastal species such as the blacktip, Carcharhinus melanopterus (Mourier et al. 2013). Segregation appeared to not reflect prey, sea surface temperature, primary productivity or temporal synchronous movements of the sexes at the regional scale, but was rather the result of spatial effects for I. oxyrinchus. Alternatively, Sphyrna lewini females segregate from males by moving to offshore habitat to feed on different, more energy-rich prey which enables increased growth rates, necessary to support large, welldeveloped embryos (Klimley 1987). Furthermore, courtship and mating in sharks is highly aggressive where males inflict serious bite wounds on females (Stevens 1974). Mucientes et al. (2009) suggest sexual segregation for some shark species may be a strategy to increase female fitness by reduced mating. Based on the example of a population of black tip sharks Carcharhinus melanopterus in Eastern Australia that exhibit a strong sex-based spatial segregation (Chin et al. 2013), and given the existence of intra-specific cannibalism amongst bull sharks (Snelson et al. 1984), bull sharks in New Caledonia may also use it as a way to facilitate reproductive and recruitment success.

Previous studies suggest some occurrence of large bull sharks in Prony Bay. For example, Clua et al. (2013) observed adult bull sharks as the shark species responsible for the killing of an exhausted blue whale calf after entering this same area. Fishing efforts in the numerous rivers along the west coast of New Caledonia revealed several small juvenile bull sharks providing evidence that localised pupping occurs which is consistent with other studies showing female's return to rivers or estuaries, probably for pupping (Tillet et al. 2011; Werry et al. 2011). Females may also remain close to rivers for feeding purposes but display divergent behaviours. We indeed observed vastly different patterns of movement across the tagged sharks, which maybe a means to better utilise coastal resources. While our sample size will need to be significantly increased to properly test this hypothesis, 
Brunnshchweiler et al. (2010) for example observed a similar pattern of long-term (years) regular occurrence of a limited number of adult bull sharks at a site in Fiji with individual adults that were more "transient" appearing infrequently or others more frequent in their occurrence on both short (days) and long-term (year) periods. Our sharks displayed both these phenomena. For example, one female adult bull shark (ID 54342) displayed ongoing occurrence "short-term residency" as opposed to the "transitory" behaviour of the second adult female bull shark (ID 54343). The emancipated shark is an anomaly that produced almost continuous detections for a period of six months suggesting this animal may have been deceased or consumed by conspecifics or other large sharks due to its poor condition or remained within a very small defined area with limited movement. Most bull sharks will consume fresh bait, rather than old rotten bait which is more frequently consumed by tiger sharks who are true generalists (Matich et al. 2011). The poor condition of this bull shark, most likely due to injury from embedded fishing line over its body, and the fact it consumed rotten bait all suggest this shark may not have had indeed a normal behaviour.

\section{Conclusion}

Given the global paucity of data for large sharks in general, further research to address the movement patterns of bull sharks should be a high priority. Firstly, because this species represents a potential threat to humans along with the tiger shark Galeocerdo cuvier and the white shark Carcharodon carcharias in New Caledonia (Clua and Séret 2010) and around the world. Secondly, because this species plays a critical role in coastal ecosystems and requires conservation measures (Werry et al. 2012; Froeschke et al. 2013). This is particularly important as large sharks move vast distances and hence are vulnerable to fishing pressures through increased chance for encounters with fisheries more often. Increasing the sample size of tagged bull sharks would enable verification of the patterns of coastal habitat use observed in females in the southern lagoon compared to the apparent transitory and more oceanic behaviour of males in the outer northern barrier reef areas. Conservation and management strategies need to consider adult male and female bull sharks appear to occur in vastly different habitats and that their movements and fidelity may differ based on sex in New Caledonia. Adult female bull sharks in the southern New Caledonian lagoon have apparent fidelity to the shallow coastal areas, however the extent of their movement from these areas was not able to be determined. Given the low catch rates of adult bull sharks in our study despite widespread fishing efforts, satellite tagging studies of both male and female adult bull sharks may provide a more effective means to investigate the extent of male and female movement in New Caledonian waters (e.g., Hammerschlag et al. 2012).

Acknowledgements. This study was conducted in the framework of the Coral Reef Initiative for the Pacific Programme (CRISP), with support of the French Pacific Fund. Authorizations for conducting these studies were provided by both the northern (DDE) and southern
(DENV) provinces authorities of New Caledonia. We wish to thank Maël Imirizaldu and Thomas Vignaud for their technical support in the field, including information on capture of juvenile sharks in rivers. Most of the logistics was kindly provided by the ACREM and we wish to thank Claude Chauvet. This research was done in accordance with permit No. 6024-4916/DENV/SMer (New Caledonia) and ethics ENV/16/08/AEC (Griffith University).

\section{References}

Baum J.K., Myers R.A., Kehler D.G., Worm. B., Harley S.J., Doherty P.A., 2003, Collapse and conservation of shark populations in the northwest Atlantic. Science 299, 389-392.

Baum J.K., Myers R.A., 2004, Shifting baselines and the decline of pelagic sharks in the Gulf of Mexico. Ecol. Lett. 7, 135-145.

Barnett A., Abrantes K.G., Seymour J., Fitzpatrick R., 2012. Residency and Spatial Use by Reef Sharks of an Isolated Seamount and Its Implications for Conservation. PLoS One 7, 5: e36574, Doi:10.1371/journal.pone.0036574.

Brunnschweiler J.M., Baensch H., 2011, Seasonal and longterm changes in relative abundance of bull sharks from a tourist shark feeding site in Fiji. PLoS One 6, 1: e16597, Doi:10.1371/journal.pone.0016597.

Brunnschweiler J.M., Queiroz N., Sims D.W., 2010, Oceans apart? Short-term movements and behaviour of adult bull sharks Carcharhinus leucas in Atlantic and Pacific Oceans determined from pop-off satellite archival tagging. J. Fish Biol. 77, 1343-1358.

Brunnschweiler J.M., Barnett A., 2013, Opportunistic visitors: longterm behavioural response of bull sharks to food provisioning in Fiji. PLoS One 8, 3: e58522, Doi:10.1371/journal.pone.0058522.

Cavanagh R., Kyne P., Fowler S.L., Musick J.A., Bennett M.B., 2003, The conservation status of Australasian chondrichthyans. Report of the IUCN Shark Specialist Group Australia and Oceania Regional Red List workshop, 7-9 March 2003, University of Queensland, Brisbane, Australia. Available at http://www.uf.edu/fish/organizations/ssg/region8/ Austfinal.pdf [accessed 1 February 2011].

Carlson J.K., Ribera M.M., Conrath C.L., Heupel M.R., Burgess G.H., 2010, Habitat use and movement patterns of bull sharks Carcharhinus leucas determined using pop-up satellite archival tags. J. Fish Biol. 77, 661-675.

Chin A., Tobin A.J., Heupel M.R., Simpfendorfer C.A., 2013, Population structure and residency patterns of the blacktip reef shark Carcharhinus melanopterus in turbid coastal environments. J. Fish Biol. 82, 1192-1210.

Compagno, L.J., 2002, FAO Species Catalogue. Sharks of the World. An annotated and illustrated catalogue of shark species known to date. Vol. 2. Bullhead, Mackerel and Carpet Sharks (Heterodontiformes, Lamniformes and Orectolobiformes). FAO, Rome.

Cortés E., 2000, Life history patterns and correlations in sharks. Rev. Fish Sci. 8, 299-344.

Cliff G., Dudley S.F.J., 1991, Sharks caught in the protective nets off Natal, South Africa. 4. The bull shark (Carcharhinus leucas) (Valenciennes). S. Afr. J. Mar. Sci. 10, 253-270.

Clua E., Séret B., 2010, Unprovoked fatal shark attack in Lifou island (Loyalty Islands, New Caledonia, South Pacific) by a great white shark, Carcharodon carcharias. Am. J. Forens. Med. Pathol. 31, 281-286. 
Clua E., Chauvet C., Read T., Werry J.M., Lee S.Y., 2013, Behavioural patterns of a tiger shark, Galeocerdo cuvier, feeding aggregation on a whale carcass in Prony Bay, New Caledonia. Mar. Freshw. Behav. Physiol. 46, 1-20.

Curtis T.H., Adams D.H., Burgess G.H., 2011, Seasonal distribution and habitat associations of bull sharks in the Indian River lagoon, Florida: A 30-year synthesis. Trans. Am. Fish. Soc. 140, 1213-1226.

Curtis T.H., Parkyn D.C., Burgess G.H., 2013, Use of human-altered habitats by bull sharks in a Florida nursery area. Mar. Coast. Fish. Dyn. Manage. Ecosyst. Sci. 5, 28-38.

Field I.C., Meekan M.G., Speed C.W., White W., Bradshaw C.J.A., 2011, Quantifying movement patterns for shark conservation at remote coral atolls in the Indian Ocean. Coral Reef. 30, 61-71.

Froeschke J.T., Froeschke J.F., Stinson C.M., 2013, Long-term trends of bull shark (Carcharhinus leucas) in estuarine waters of Texas, USA. Can. J. Fish. Aquat. Sci. 70, 13-21.

Hammerschlag N., Luo J., Irschick D.J., Ault J.S., 2012, A comparison of spatial and movement patterns between sympatric predators: bull sharks (Carcharhinus leucas) and Atlantic tarpon (Megalops atlanticus). PLoS One 7, 9: e45958, Doi:10.1371/journal.pone.0045958.

Heupel M.R., Simpfendorfer C.A., Fitzpatrick R., 2010, Large-scale movement and reef fidelity of grey reef sharks. PLoS One 5, 3: e9650, Doi:10.1371/journal.pone.0009650.

Heupel M.R., Simpfendorfer C.A., 2008, Movement and distribution of young bull sharks Carcharhinus leucas in a variable estuarine environment. Aquat. Biol. 1, 277-289.

Heupel M.R., Semmens J.M., Hobday A.J., 2006, Automated acoustic tracking of aquatic animals: scales, design and deployment of listening station arrays. Mar. Freshw. Res. 57, 1-13

Heupel M.R., Hueter R.E., 2002, Importance of prey density in relation to the movement patterns of juvenile blacktip sharks (Carcharhinus limbatus) within a coastal nursery area. Mar. Freshw. Res. 53, 543-550.

Hoenig J.M., Gruber S.H., 1990, Life-History Patterns in the Elasmobranchs: implications for fisheries management. In: Pratt Jr. H.L., Gruber S.H., Taniuchi T. (Eds). Elasmobranchs as living resources: advances in the biology, ecology, systematics, and the status of the fisheries. NOAA Tech Report 90.

IUCN, 2008, Carcharhinus leucas IUCN (International Union for Conservation of Nature) Red list of threatened species. Available at www. iucnredlist.org [accessed 15 March 2010].

Klimley A.P., 1987, The determinants of sexual segregation in the scalloped hammerhead shark, Sphyrna lewini. Environ. Biol. Fish. 18, 27-40.

Lacroix G.L., Voelgeli F.A., 2000, Development of automated monitoring systems for ultrasonic transmitters. In: Moore A.R. (Ed.) Advances in fish telemetry. CEFAS, Suffolk, pp. 37-50.

Lacroix G.L., McCurdy P., 1996, Migratory behaviour of post-smolt Atlantic salmon during initial stages of seaward migration. J. Fish Biol. 49, 1086-1101.

Letourneur Y., Kulbicki M., Labrosse P., 2000, Fish stock assessment of the Northern New Caledonian lagoons: 1- Structure and stocks of coral reef fish communities. Aquat. Living Resour. 13, 65-76.

Matich P., Heithaus M.R., Layan C.A., 2011, Contrasting patterns of individual specialization and trophic coupling in two marine apex predators. J. Anim. Ecol. 80, 294-305.

Meyer C.G., Clark T.B., Papastamatiou Y.P., Whitney N.M., Kim N. Holland K.N., 2009, Long-term movement patterns of tiger sharks Galeocerdo cuvier in Hawaii. Mar. Ecol. Prog. Ser. 381, 223-235.
McCord M.E., Lamberth S.J., 2009, Catching and tracking the world's largest zambezi (bull) shark Carcarhinus leucas in the Breede estuary, South Africa: the first 43 hours. Afr. J. Mar. Sci. 31, 107-111.

Mollet H.F., Cailliet G.M., 2002, Comparative population demography of elasmobranchs using life history tables, Leslie matrices and stage-based matrix models. Mar. Freshw. Res. 53, 503-515.

Mourier J., Planes S., Buray N., 2013, Trophic interactions at the top of the coral reef food chain. Coral Reef 32, 285.

Mourier J., Vercelloni J., Planes S., 2011, Evidence of social communities in a spatially structured network of a free-ranging shark species. Anim. Behav. 83, 389-401.

Mucientes G.R., Queiroz N., Sousa L.L., Tarroso P., Sims D.W., 2009, Sexual segregation of pelagic sharks and the potential threat from fisheries. Biol. Lett. 5, 156-159.

Myers R.A., Baum J.K., Shepherd T.D., Powers S., Peterson C.H., 2007, Cascading effects of the loss of apex predatory sharks from a coastal ocean. Science 315, 1846-1850.

Myers R.A., Worm B., 2003, Rapid worldwide depletion of predatory fish communities. Nature 423, 280-284.

Noriega R., Werry J.M., Sumpton W., Mayer D., Lee S.Y., 2011, Trends in annual CPUE and evidence of sex and size segregation of Sphyrna lewini: management implications in coastal waters of north eastern Australia. Fish. Res. 110, 472-477.

Otway N.M., Ellis M.T., 2011, Pop-up archival satellite tagging of Carcharias taurus: movements and depth/temperature-related use of south-east Australian waters. Mar. Freshw. Res. 62, 607-620.

Pillans R.D., Anderson W.G., Goode J.P., Hyodo S., Takei Y., Hazon N., Franklin C.E., 2006, Plasma and erythrocyte solute properties of juvenile bull sharks, Carcharhinus leucas, acutely exposed to increasing environmental salinity. J. Exp. Mar. Biol. Ecol. 331, $145-157$.

Simpfendorfer C.A., Heupel M.R., Collins A.B., 2008, Variation in the performance of acoustic receivers and its implication for positioning algorithms in a riverine setting. Can. J. Fish. Aquat. Sci. 65, 482-492.

Simpfendorfer C., Freitas G., Wiley T., Heupel M., 2005, Distribution and habitat partitioning of immature bull sharks (Carcharhinus leucas) in a Southwest Florida estuary. Estuaries 28, 78-85.

Snelson F.F., Mulligan T.J., Williams S.E., 1984, Food habits, occurrence, and population structure of the bull shark, Carcharhinus leucas, in Florida coastal lagoons. Bull. Mar. Sci. 34, 71-80.

Speed C.W., Field I.C., Meekan M.J., Bradshaw C.J.A., 2010, Complexities of coastal shark movements and their implications for management. Mar. Ecol. Prog. Ser. 408, 275-293.

Speed C.W., Meekan M.G., Field I.C. McMahon C.R., Stevens J.D., McGregor F., Huveneers C., Berger Y., Bradshaw C.J.A., 2011, Spatial and temporal movement patterns of a multispecies coastal reef shark aggregation. Mar. Ecol. Prog. Ser. 429, 261-275.

Stevens J.D., 1974, The occurrence and significance of tooth cuts on the blue shark (Prionace glauca L.) from British waters. J. Mar. Biol. Assoc. UK 54, 373-378.

Thorson T.B., 1971, Movements of bull sharks, Carcharhinus leucas, between the Caribbean Sea and Lake Nicaragua demonstrated by tagging. Copeia 2, 336-338, Doi:10.2307/1442846.

Thorson T.B., Cowan, C.M., Watson, D.E., 1973, Body fluid solutés of juveniles and adults of the euryhaline bull shark Carcharhinus leucas from freshwater and saline environments. Physiol. Zool. 46, 29-42.

Tillet B.J., Meekan M.G., Field I.C., Hua Q., Bradshaw C.J.A., 2011, Similar life history traits in bull (Carcharhinus leucas) and pigeye (C. amboinensis) sharks. Mar. Freshw. Res. 62, 850-860. 
Tillett B.J., Meekan M.G., Field I.C., Thorburn D.C., Ovenden J.R., 2012, Evidence for reproductive philopatry in the bull shark Carcharhinus leucas. J. Fish Biol. 80, 2140-2158.

Torres L.G., Heithaus M.R., Delius B., 2006, Influence of teleost abundance on the distribution and abundance of sharks in Florida Bay, USA. Hydrobiologia 569, 449-455.

Virly S., 2008, Atlas cartographique des mangroves de NouvelleCalédonie. Programme d'évaluation des ressources marines de la zone économique de Nouvelle-Calédonie (ZonEco).

Voegeli F.A., Lacroix G.L., Anderson J.M., 1998, Development of miniature pingers for tracking Atlantic salmon smolts at sea. Hydrobiologia 371/372, 35-46.
Werry J.M., Lee S.Y., Otway N., Hu Y., Sumpton W., 2011, A multi-faceted approach for quantifying the estuarine-nearshore lifecycle transition of the bull shark, Carcharhinus leucas. Mar. Freshw. Res. 62, 1421-1431.

Werry J.M., Lee S.Y., Lemckert C.J., Otway N.M., 2012, Natural or artificial? Habitat-use by the bull shark, Carcharhinus leucas. PLoS One 7, 11: e49796, Doi:10.1371/journal.pone.0049796.

Yeiser B.G., Heupel M.R., Simpfendorfer C.A., 2008, Occurrence, home range and movement patterns of juvenile bull (Carcharhinus leucas) and lemon (Negaprion brevirostris) sharks within a Florida estuary. Mar. Freshw. Res. 59, 489-501. 